\title{
PENGAMATAN KEJADIAN HUJAN DENGAN DISDROMETER DAN MICRO RAIN RADAR DI SERPONG
}

\author{
Observation of Rain Events with Disdrometer and Micro Rain Radar \\ in Serpong Area
}

\author{
Findy Renggono ${ }^{\left.1^{*}\right)}$ \\ 1) Balai Besar Teknologi Modifikasi Cuaca - Badan Pengkajian dan Penerapan Teknologi, Gedung Ir. \\ Mohammad Soebagio, GEOSTECH (820), Kawasan PUSPIPTEK, Serpong, Tangerang Selatan \\ *E-mail : findy.renggono@bppt.go.id
}

\begin{abstract}
Intisari
Pengamatan hujan dengan menggunakan beberapa peralatan yang mempunyai metode berbeda telah dilakukan di wilayah Serpong. Peralatan yang digunakan adalah Disdrometer dan Micro Rain Radar (MRR). Kedua peralatan tersebut dipasang pada satu lokasi yang sama agar dapat mengukur kejadian hujan yang sama. Pengamatan dilakukan pada akhir tahun 2016 selama 5 bulan, disesuaikan dengan kondisi dimana musim hujan sudah mulai masuk untuk wilayah ini. Perbandingan pengukuran yang telah dilakukan menunjukkan kesesuaian hasil antara kedua peralatan tersebut. Pengamatan distribusi ukuran butir air pada empat kejadian hujan antara bulan Agustus-Desember 2016 menunjukkan bahwa hujan konvektif mempunyai distribusi ukuran yang lebih besar dibandingkan hujan stratiform.
\end{abstract}

Kata Kunci : Curah Hujan, Disdrometer, Micro Rain Radar.

\begin{abstract}
Rain observation by using several instruments having different method has been done in Serpong area. The instrument used is Disdrometer and Micro Rain Radar (MRR). Both instruments are installed in the same location in order to measure the same rain events. Observations were made at the end of 2016 for 5 months, adjusted to the conditions in which the rainy season has begun to enter for the region. Comparison of measurements that have been done indicate the suitability of the results between the two instrument. Drop size distribution of four rain event during August December 2016 shows that the drop size distribution on convective rain broaden than on stratiform rain.
\end{abstract}

Keywords : Rainfall Rate, Disdrometer, Micro Rain Radar.

\section{PENDAHULUAN}

Pengamatan hujan secara akurat penting salah satunya adalah untuk meningkatkan kualitas prediksi cuaca. Beberapa peralatan pengukuran hujan dengan berbagai metode telah banyak diciptakan untuk hal tersebut. Pada penakar hujan yang banyak dipakai secara umum biasanya hanya dapat mengukur jumlah total curah hujannya saja, namun pada saat ini bukan hanya curah hujan saja yang dapat diukur, akan tetapi ukuran, jumlah, bentuk maupun kecepatan jatuh butir air juga dapat dihitung. Bahkan bukan hanya di permukaan saja, namun yang berada jauh di atas permukaan pun sanggup diperkirakan distribusi butir airnya.

Disdrometer adalah alat yang selain mengukur curah hujan, juga dapat mengukur ukuran, jumlah dan kecepatan butir hujan di permukaan. Sedangkan Micro Rain Radar (MRR) mempunyai kemampuan yang sama dengan disdrometer namun untuk lokasi yang di atas permukaan sampai ketinggian di atas $7 \mathrm{~km}$. Walaupun mempunyai kemampuan yang sama namun kedua alat ini mempunyai perbedaan dalam metode pengambilan datanya sehingga beberapa perbedaan hasil pengukuran akan timbul.

Pengamatan hujan dengan MRR maupun disdrometer telah dilakukan oleh beberapa peneliti di beberapa lokasi. Peters et al, (2002, 2005) melakukan penelitian pengamatan hujan dengan MRR untuk melihat distribusi butir air, Kirankumar \& Kunhikrishnan (2013) melakukan evaluasi MRR dengan membandingkan dengan data disdrometer di India, dan Nikolopoulos et al. (2008) melakukan perbandingan hujan dengan berbagai peralatan di Amerika.

Di Indonesia, pengamatan hujan dengan peralatan selain penakar hujan manual sudah dilakukan sejak sebelum tahun 2002. Di Bukit Tinggi, Renggono et al. (2002) melakukan perbandingan pengamatan disdrometer dengan penakar hujan. Kozu et al. (2005) melakukan 
studi tentang distribusi ukuran butir air hujan antar musim menggunakan data video disdrometer 2-D, sedangkan Marzuki et al. (2016) melakukan evaluasi kemampuan MRR Bukit Tinggi dibandingkan dengan disdrometer dan WPR. Sedangkan perbandingan antara pengamatan disdrometer dengan data dari satelit komunikasi Ku-band dilakukan oleh Indrayani et al. (2016).

Pengamatan karakteristik hujan di pulau Jawa belum banyak dilakukan, terutama sebaran butir hujannya. Oleh karena itu Balai Besar Teknologi Modifikasi Cuaca, BPPT bersamasama dengan BMKG melakukan pengamatan hujan bersama pada awal tahun 2016 di Bogor dengan menggunakan Radar, MRR, disdrometer, radiometer dan radiosonde. Beberapa hasil awal dari pengamatan tersebut antara lain: perbandingan pengukuran antara radar dengan MRR terhadap profil hujan dilakukan oleh Sunu et al. (2016), studi karakteristik temporal dan spasial hujan di DKI dilakukan oleh Destianingrum et al. (2016), sedangkan studi untuk kestabilan atmosfir dilakukan dengan analisis data radiosonde (Alfan et al., 2016).

Penelitian tersebut dilanjutkan kemudian di Puspitek Serpong dengan memasang MRR dan disdrometer pada pertengahan tahun 2016 sampai awal tahun 2017. Pada tulisan ini dua buah peralatan pengukur hujan yang menggunakan metode berbeda akan dibandingkan dalam mengamati kejadian hujan yang terjadi di Serpong. Alat yang digunakan adalah MRR dan disdrometer. Selain curah hujannya, juga karakteristik distribusi ukuran butir air (selanjutnya akan disebut sebagai DSD, Drop Size Distribution) juga dibahas dalam tulisan ini.

\section{METODE}

Pada tulisan ini digunakan dua buah alat yang dapat mengukur curah hujan sekaligus distribusi ukuran butir hujannya. MRR adalah alat yang dapat mengukur distribusi butir hujan dari ketinggian $50 \mathrm{~m}$ sampai lebih dari $7 \mathrm{~km}$ pada 32 level ketinggian (efektif hanya 30 level karena level pertama adalah permukaan dan yang terakhir dianggap terlalu banyak noise), bergantung pada kerapatan pengukurannya, sedangkan disdrometer mengukur distribusi jumlah dan ukuran butir hujan yang sampai di permukaan.

Untuk mendapatkan pengukuran hujan di wilayah Serpong, MRR dan disdrometer dipasang di atap gedung BBTMC-Geostech, BPPT di Puspiptek Serpong (6.36S, 106.7E). Pengamatan dengan MRR sudah dilaksanakan sejak Maret 2016, sedangkan disdrometer baru dimulai sejak bulan Agustus 2016. Pada tulisan ini digunakan data bulan Agustus sampai Desember 2016. Ketersediaan data dapat dilihat pada Tabel 1. Seluruh data hasil pengamatan yang tersimpan dalam komputer diolah dengan Fortran dan GRADs.

Secara umum data pengamatan dengan kedua alat ini dapat diperoleh dengan baik, namun ada beberapa hari tanpa pengamatan yang disebabkan karena masalah teknis. Tanggal 15-17 Agustus tidak ada pengamatan dengan MRR karena terjadi kerusakan pada data akuisisi sehingga menyebabkan tidak adanya data pada ketiga hari tersebut. Sedangkan data disdrometer baru bisa diperoleh sejak tanggal 14 Agustus karena alat ini baru dipasang tanggal 12 Agustus. Selain itu juga terjadi beberapa kali tidak mendapatkan data (tanggal 26-31 Agustus, 27 September - 2 Oktober) dikarenakan adanya kerusakan pada sistem komputer utama disdrometer yang terkena petir.

\subsection{Micro Rain Radar}

MRR yang digunakan pada tulisan ini adalah buatan METEK tipe MRR-2. Alat yang menggunakan sebuah parabola berdiameter 70 $\mathrm{cm}$ yang diarahkan tegak ke atas ini menggunakan gelombang radio dengan panjang gelombang $1.25 \mathrm{~cm}$ untuk mendapatkan profil sebaran butir hujan. Pada tulisan ini MRR yang mempunyai daya $50 \mathrm{~mW}$ ini diatur sehingga dapat mengetahui profil dari reflektifitas, LWC, curah hujan, dan kecepatan jatuh untuk ketinggian 250 m sampai $7.750 \mathrm{~m}$ dengan kerapatan jarak 250 m. Ukuran butir hujan yang mampu dideteksi adalah antara $0.25 \mathrm{~mm}$ sampai $4.53 \mathrm{~mm}$, sedangkan ukuran yang lebih besar biasanya akan terpecah menjadi butir-butir yang lebih kecil karena terkena hambatan udara ketika jatuh.

Tabel 1. Ketersediaan Data Pengamatan dengan MRR dan Disdrometer.
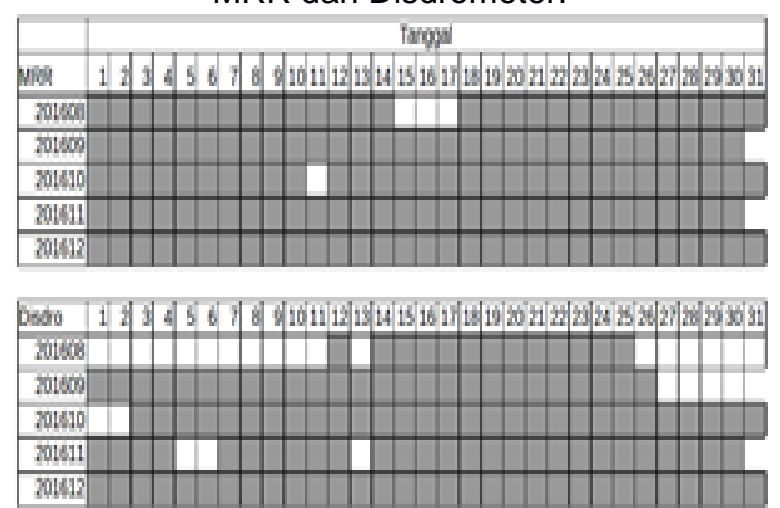

Dari DSD, parameter-parameter yang dihasilkan dihitung dengan persamaan di bawah ini (Peters et al., 2002) :

Nilai reflektifitas $(Z)$ dihitung dengan persamaan:

$$
Z_{e}=Z=\int_{0}^{\infty} N(D) D^{6} d D
$$

di sini $N(D)$ adalah jumlah butir air hujan untuk 
ukuran diameter D. Karena panjang gelombang MRR pendek, maka nilai equivalent radar reflectivity factor $(Z e)$ sama dengan nilai $Z$.

Nilai LWC didapat dari volume total dari seluruh droplet dengan densitas air $\rho w$ dibagi dengan volume.

$$
\mathrm{LWC}=\rho_{w} \frac{\pi}{6} \int_{D_{\min }}^{D_{\max }} N(D) D^{3} d D
$$

Nilai curah hujan $R$ dihitung dengan persamaan:

$$
R=\frac{\pi}{6} \int_{D_{\min }}^{D_{\max }} N(D) v(D) D^{3} d D
$$

\subsection{Disdrometer}

Disdrometer yang digunakan adalah sebuah Laser Precipitation Monitor merk ThiesClima tipe 5.4110.01.200. Alat ini dapat mengukur sebaran butir hujan dipermukaan dengan cara mengamati partikel yang jatuh melewati pancaran sinar infra merah. Diameter partikel diukur dari besarnya pengurangan intensitas, sedangkan kecepatan jatuh diukur dari lamanya pengurangan intensitas sinyalnya. Seluruh pengukuran diproses untuk mendapatkan intensitas, kualitas, jenis presipitasi dan distribusi partikel.

Panjang gelombang diode laser adalah $785 \mathrm{~nm}$ dengan daya optik $0.5 \mathrm{~mW}$. Wilayah pengukuran dari disdrometer adalah sekitar 40$47 \mathrm{~cm}^{2}$ dan diameter butir air yang dapat diukur antara 0.16 sampai lebih dari $8 \mathrm{~mm}$ dengan kecepatan jatuh antara 0.2 sampai $20 \mathrm{~m} /$ detik.

\section{HASIL DAN PEMBAHASAN}

Hujan yang diamati pada penelitian ini adalah kejadian hujan yang muncul sebelum masuk puncak musim hujan sampai musim hujan. Aldrian et al. (2000 \& 2003) menyebutkan bahwa wilayah Jabodetabek mempunyai pola hujan monsun, yaitu mempunyai satu puncak musim hujan (Desember-Februari) dan musim kemarau (Juni-Agustus). Oleh karena itu data yang digunakan adalah bulan Agustus sampai Desember 2016.

Berdasarkan data di stasiun klimatologi BMKG Pondok Betung (sekitar 13km dari Serpong) rata-rata hujan bulanan untuk bulan Agustus-Desember antara tahun 1981-2010 adalah sekitar 137-239 mm. Hasil pengukuran curah hujan dengan AWS di Serpong pada akhir tahun 2016 menunjukan kondisi yang cukup basah. Curah hujan bulanan yang terukur adalah sekitar 180-250 mm dengan jumlah hari hujan antara 15-22 hari/bulan (Gambar 1).

Hal ini menunjukkan bahwa selama kegiatan pengamatan ini, curah hujannya kurang lebih sama dengan rata-rata. Dari kondisi ENSO menunjukkan bahwa nilai anomali nino3.4 antara -0.8 sampai dengan -0.3. Sebagai bahan perbandingan, diambil tiga kejadian hujan selama periode pengamatan ini, yaitu tanggal 19 Agustus, 24 September, 22 Oktober dan 27 Nopember 2016.

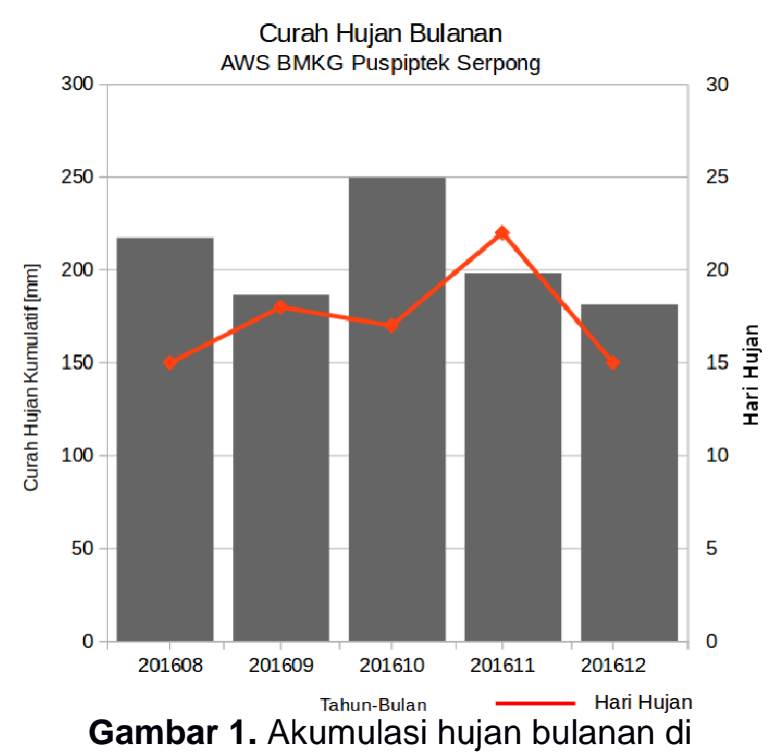

Puspiptek Serpong.

\subsection{Pengamatan dengan MRR}

Dari pengukuran MRR didapat beberapa parameter seperti yang telah dijelaskan pada rumus (1)-(3). Parameter yang berupa reflektifitas, curah hujan, LWC dan kecepatan jatuh diperoleh pada setiap menit dan untuk 30 level ketinggian dari $250 \mathrm{~m}$ sampai $7.750 \mathrm{~m}$. Seluruh nilai ini dihitung secara online oleh MRR2-control dalam sebuah komputer, termasuk koreksi noise dan atenuasi.

Hasil pengamatan kejadian hujan tgl 24 September 2016 dapat dilihat pada gambar 2 . Pada gambar ini terlihat bahwa reflektifitas yg kuat terjadi antara pukul 8-10 UTC (Gambar 2.c) yang bersesuaian dgn meningkatnya nilai kecepatan jatuh butir air (Gambar 2.b) dan nilai LWC (Gambar 2.a). Reflektifitas radar yg kuat yang menjulang dari permukaan sampai 3-5 km ini menunjukkan bahwa hujan yg terjadi adalah hujan konvektif (Renggono et al., 2001).

Sedangkan pada pukul 10-12 UTC nilai reflektifitas terlihat lebih rendah dibandingkan sebelumnya. Kecepatan jatuh hanya terlihat besar di sekitar ketinggian $4 \mathrm{~km}$, dan LWC juga hanya terlihat di sekitar 4-5 km dari permukaan. Pada ketinggian ini temperatur udara sudah dibawah nol derajat. Dari data profil temperatur yg diukur oleh radiometer diketahui bahwa freezing level berada pada ketinggian $4 \mathrm{~km}$. Karakteristik reflektifitas seperti ini adalah jenis hujan stratiform. Biasanya awan hujan stratiform dapat bertahan lama namun curah hujannya rendah, sedangkan hujan konvektif mempunyai curah hujan tinggi namun dalam durasi waktu yang singkat. 

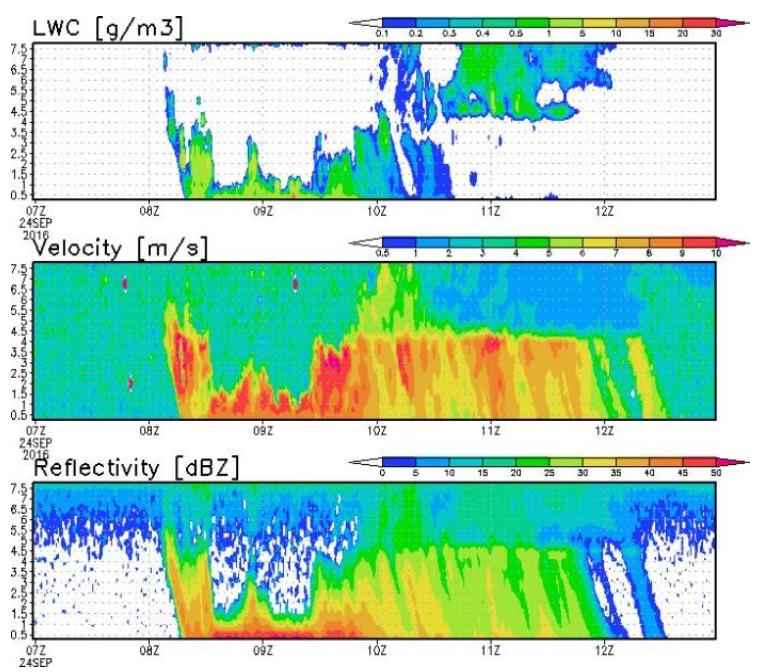

Gambar 2. Pengamatan hujan tanggal 24 September 2016 dengan MRR untuk LWC (a), kecepatan jatuh (b) dan reflektifitas (c).

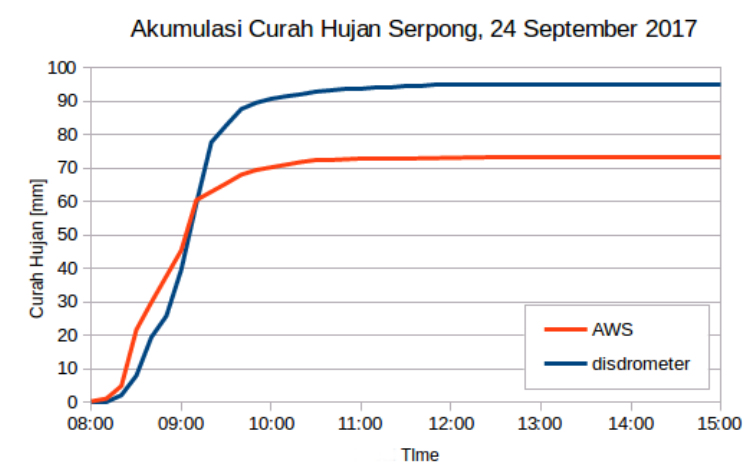

Gambar 3. Akumulasi curah hujan yang diukur oleh AWS (merah) dan disdrometer (biru).

Dari data penakar hujan milik BMKG yang terletak di Serpong, maupun pengamatan dengan disdrometer diketahui bahwa curah hujan yang tinggi terjadi antara pukul 8 sampai 10 , sedangkan setelah pukul 10 curah hujan sangat rendah (Gambar 3). Perbedaan pengukuran ini terjadi karena AWS menggunakan system tipping bucket untuk mengukur jumlah hujan yang turun pada suatu waktu tertentu. Menurut Liu et al. (2013), sistem tipping bucket mengukur hujan lebih sedikit, terutama pada saat curah hujan di bawah kapasitas bucketnya.

\subsection{Perbandingan Curah Hujan}

Perbandingan pengukuran akumulasi 10 menit curah hujan untuk ke-empat kejadian hujan dapat dilihat pada Gambar 4. Gambar ini menunjukkan perbandingan antara pengukuran MRR (garis biru) dan disdrometer (garis merah) yang terletak di Serpong untuk empat kejadian hujan. Karena disdrometer mengukur curah hujan pada level permukaan, maka untuk mendapatkan perbandingan yang sesuai, digunakan data MRR dari level yang paling dekat dengan permukaan, yaitu data pada level $250 \mathrm{~m}$.

Dari Gambar 4 terlihat bahwa kedua data mempunyai korelasi yang cukup baik. Namun ada beberapa kondisi yang menunjukkan nilai MRR lebih tinggi daripada disdrometer, yaitu tanggal 19 Agustus sekitar pukul 12.00-13.30 UTC (Gambar 4.a) dan tanggal 24 September sekitar pukul 8.00-10.00 UTC (Gambar 4.b), maupun sebaliknya yaitu tanggal 22 Oktober sekitar pukul 13.00-13.30 UTC (Gambar 4.c) dan tangal 27 November sekitar pukul 5.00-6.00 UTC (Gambar 4.d). Walaupun demikian, koefisien korelasi untuk masing-masing kejadian hujan masih cukup tinggi, yaitu antara 8.5-9.5.

Gambar 5 merupakan perbandingan antara seluruh kejadian hujan yang terjadi antara bulan Agustus-Desember 2016. Dalam 5 bulan
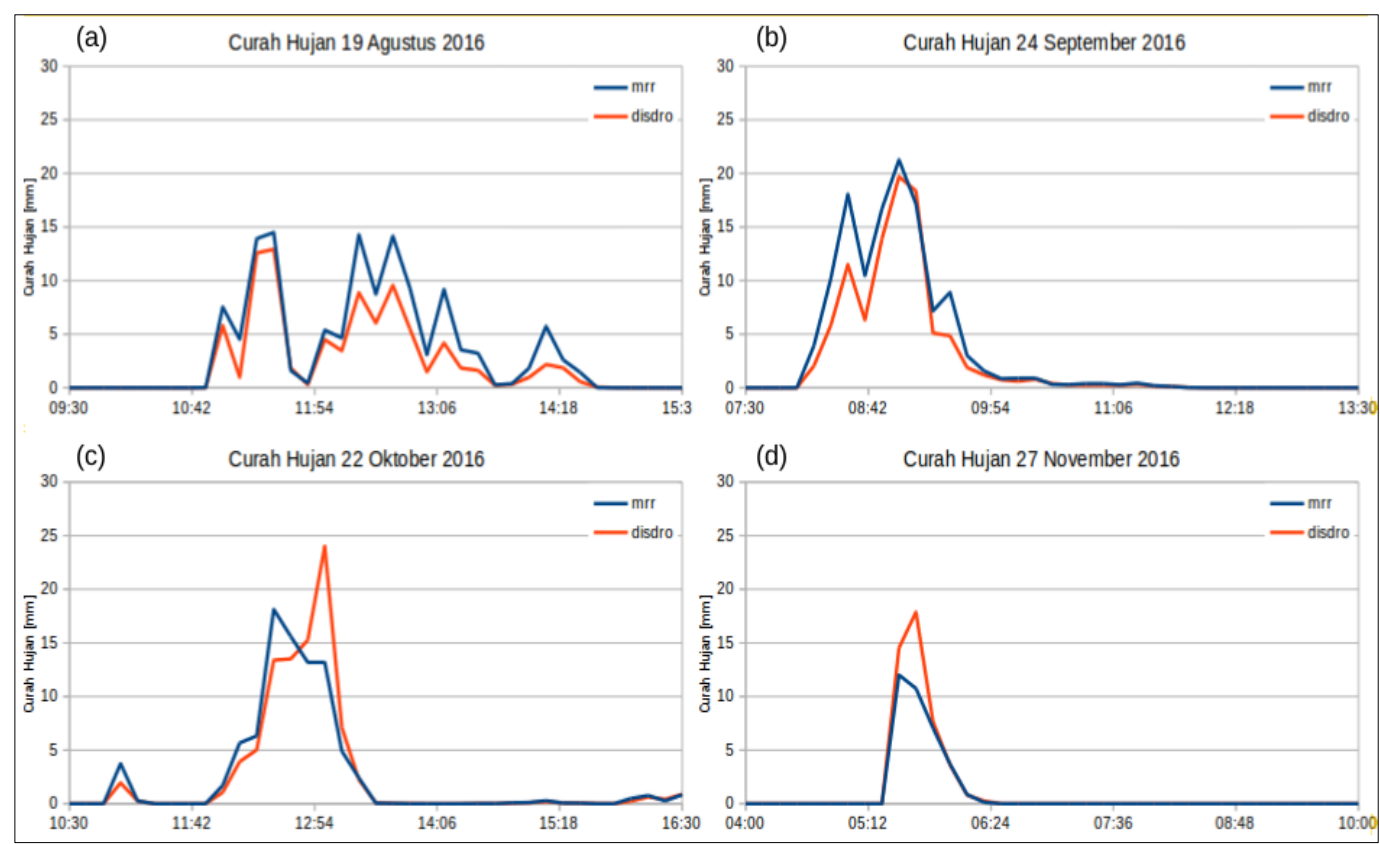

Gambar 4. Perbandingan antara pengukuran dengan MRR (garis biru) dan disdrometer (garis merah) untuk 19 Agustus (a), 24 September (b), 22 Oktober (c) dan 27 November (d). 
telah terjadi beberapa kejadian hujan yang kemudian terbagi menjadi 193 data hujan 10menitan, dengan jumlah akumulasi curah hujan terendah dan tertinggi masing-masing 1 $\mathrm{mm}$ dan $25 \mathrm{~mm}$.

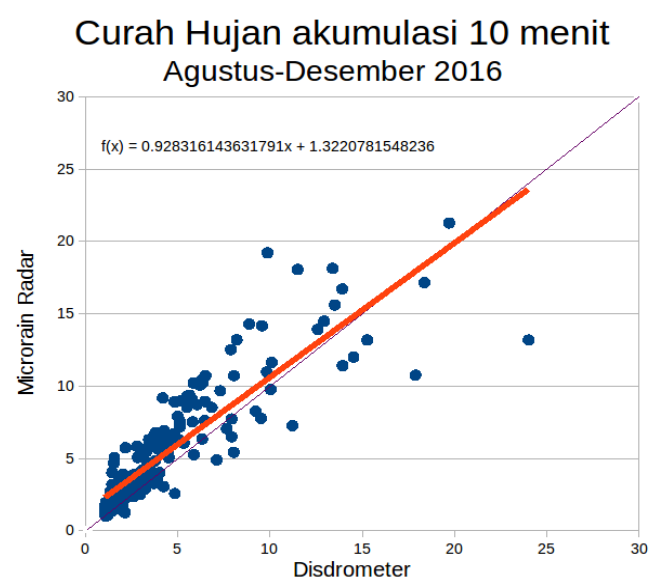

Gambar 5. Perbandingan MRR dengan disdrometer bulan Agustus-Desember 2016.
Garis merah pada gambar tersebut merupakan garis kecenderungan data (garis trend) yang terlihat hampir berhimpit dengan garis $1: 1$. Persamaan garis tersebut adalah $y=$ $0.93 x+1.32$ dengan koefisien korelasi 0.88 .

Pada gambar ini juga terlihat curah hujan kurang dari $5 \mathrm{~mm}$ lebih banyak terjadi, dan pada saat hujan nilai MRR lebih tinggi dibandingkan disdrometer. Hujan di atas $10 \mathrm{~mm}$ nilainya tersebar di kedua sisi. Total hujan berdasarkan pengukuran MRR dan disdrometer masingmasing adalah 1017.55 dan $821.3 \mathrm{~mm}$.

\subsection{Perbandingan Distribusi Ukuran Butir Air}

Perbadingan DSD di permukaan untuk empat kejadian hujan ditunjukkan pada gambar 6 (a-h). Gambar ini merupakan DSD dari MRR $(a, c, e, g)$ dan disdrometer (b,d,f,h). Sumbu tegak adalah ukuran butir air (D) sedangkan warna kontur adalah jumlah dari masing-masing ukuran $(\log N(D))$.
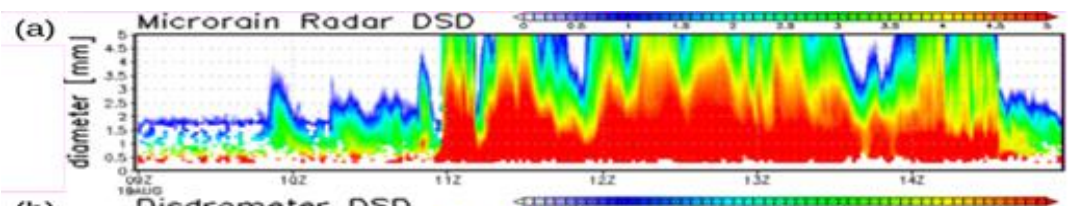

(b)

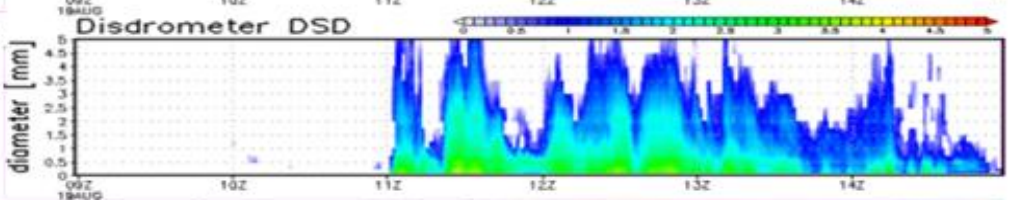

(c)

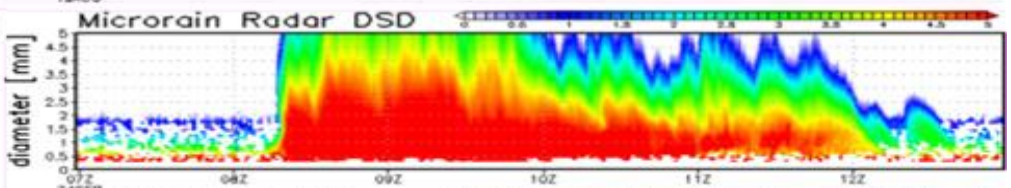

(d)

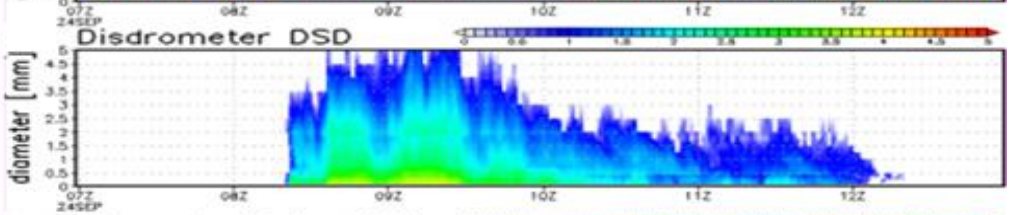

(e)

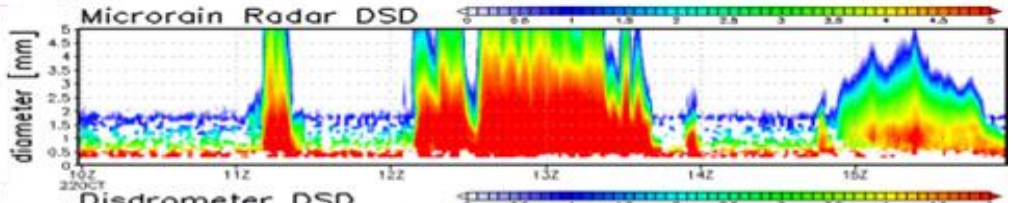

(f)
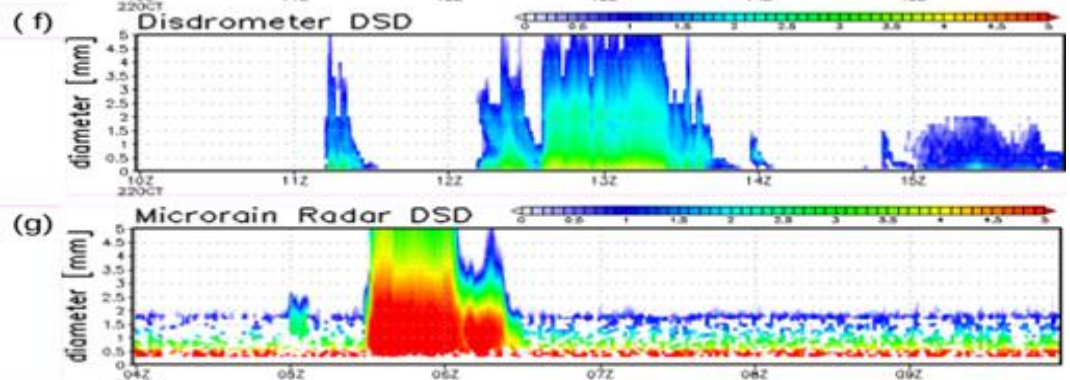

(h)

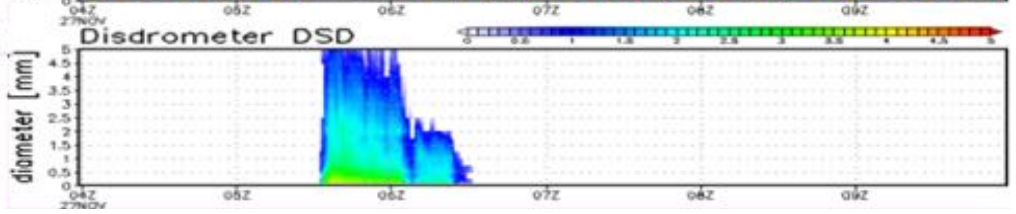

Gambar 6. Perbandingan MRR dengan disdrometer untuk tanggal 19 Agustus (a,b), 24 September (c,d), 22 Oktober (e,f) dan 27 Nopember 2016 (g,h). 
Nilai jumlah DSD untuk masing-masing ukuran pada MRR terlihat lebih tinggi dibandingkan disdrometer. Selain itu juga pada saat tidak ada hujan di permukaan, MRR mendeteksi adanya butir air ukuran 1-3mm pada ketinggian $250 \mathrm{~m}$ dari tanah. Sebagai contoh adalah kejadian hujan pada tanggal 19 Agustus pukul 10-11 UTC (Gambar 6.a). Jika melihat profil MRR, pada saat tersebut terlihat reflektifitas lemah (kurang dari $15 \mathrm{dBZ}$ ) dari permukaan sampai ketinggian $5 \mathrm{~km}$.

Pada hujan konvektif terlihat sebaran ukuran butir hujannya lebih lebar, dari butir yang terkecil sampai $5 \mathrm{~mm}$, sedangkan pada saat hujan stratiform sebaran ukuran butir hujannya lebih sempit. Sebagai contoh dapat dilihat pada kejadian hujan stratiform tanggal 24 September 2016 pukul 10-12 UTC (Gambar 6.c-d) dan 22 Oktober pukul 15 - 16 (Gambar 6.e-f). Hasil ini sesuai dengan pengamatan dengan disdrometer di Bukittinggi, Renggono (2002) yang menyatakan bahwa pada saat hujan konvektif butir yang berukuran kecil jumlahnya lebih sedikit dibandingkan pada saat hujan stratiform.

\section{KESIMPULAN}

Perbandingan curah hujan akumulasi 10 menit antara MRR dengan disdrometer menunjukkan hasil yang baik dengan koefisien korelasi 0.88. Pada saat curah hujan rendah, nilai MRR sedikit lebih tinggi dibandingkan disdrometer, sedangkan pada saat curah hujan tinggi nilainya tersebar di kedua sisi garis 1:1. Secara umum, MRR mengukur lebih tinggi dibandingkan disdrometer. Perbedaan pengukuran ini timbul selain karena perbedaan metode pengukuran, juga lokasi curah hujan yang diukur berbeda. Disdrometer mengukur hujan di permukaan dengan menghitung butir hujan yang jatuh melalui sinar laser pada wilayah yang tidak begitu besar. Sedangkan MRR mengukur hujan pada ketinggian $250 \mathrm{~m}$ dari permukaan tanah dengan gelombang radio pada frekuensi tinggi yang sangat rawan dengan atenuasi. Maka pada saat hujan deras, hasil pengukuran akan lebih kecil dibandingkan dengan hujan yang sebenarnya.

Sebaran DSD untuk awan hujan konfektif lebih luas daripada awan stratiform. Jumlah DSD hasil pengukuran MRR lebih banyak dibandingkan disdrometer.

\section{DAFTAR PUSTAKA}

Aldrian, E. (2000). Pola Hujan Rata-Rata Bulanan Wilayah Indonesia; Tinjauan Hasil Kontur Data Penakar dengan Resolusi ECHAM T-42. Jurnal Sains \& Teknologi Modifikasi Cuaca, 1(2), 113-123.

Aldrian, E., Gates, L.D., Widodo, F.H. (2003). Variability of Indonesian Rainfall and the
Influence of ENSO and Resolution in ECHAM4 Simulations and in the Reanalyses. MPI Report 346, 30pp. Max Planck-Institut für Meteorologie, Hamburg, Germany.

Indrayani, W., Marzuki., Vonnisa, M. (2016). Estimation of Raindrop Size Distribution Parameters Using Rain Attenuation Data from a Ku-Band Communications Satellite, Makara Journal of Science, 20(3), 145154. doi: $10.7454 / \mathrm{mss} . v 20 i 3.6245$.

Kirankumar, N.V.P., Kunhikrishnan, P.K. (2013). Evaluation of Performance of Micro Rain Radar over the Tropical Coastal Station Thumba $\left(8.5^{\circ} \mathrm{N}, 76.9^{\circ} \mathrm{E}\right)$. Atmospheric Research, 134, 56-63. doi: 10.1016/j.atmosres.2013.07.018

Kozu, T., Shimomai, T., Akramin, Z., Marzuki., Shibagaki, Y., Hashiguchi, H. (2005). Intraseasonal Variation of Raindrop Size Distribution at Koto Tabang, West Sumatra, Indonesia. Geophysical Reseach Letters, 32(7) doi: 10.1029/2004GL022340

Liu, X.C., Gao, T.C., Liu, L. (2013). A Comparison of Rainfall Measurements from Multiple Instruments. Atmospheric Measurement Technique, 6, 1585-1595.

Marzuki., Hashiguchi, H., Shimomai, T., Rahayu, I., Vonnisa, M., Afdal. (2016). Performance Evaluation of Micro Rain Radar over Sumatra Through Comparison with Disdrometer and Wind Profiler. Progress In Electromagnetics Research M, 50, 33-46. doi: 10.2528/PIERM16072808

Muttaqin, A., Muhammad, F.N., Abdillah, P.A. (2016). Analisis Profil CAPE (Convective Available Potential Energy) Selama Kegiatan Intensive Observation Period di Dramaga Bogor. Jurnal Sains \& Teknologi Modifikasi Cuaca, 17(2), 83-89.

Nikolopoulos, E.I., Kruger, A., Krajewski, W.F., Williams, C.R., Gage, K.S. (2008). Comparative Rainfall Data Analysis from Two Vertically Pointing Radars, an Optical Disdrometer, and a Rain Gauge, Nonlinear Processes Geophysics, 15(6), 987-997. doi: 10.5194/npg-15-987-2008

Peters, G., Fischer, B., Andersson, T. (2002). Rain Observations with a Vertically Looking Micro Rain Radar (MRR). Boreal Environment Reseach, 7. 353-362.

Peters, G., Fischer, B., Munster, H., Clemens, M., Wagner, A. (2005). Profiles of Raindrop Size Distributions as Retrieved by Microrain Radars. Journal Applied Meteorology and Climatogy, 44(12), 1930 1949. doi: 10.1175/JAM2316.1

Prabawadhani, D,R., Harsoyo, B., Seto, T.H., and Prayoga, M.B.R. (2016). Karakteristik Temporal dan Spasial Curah Hujan Penyebab Banjir di Wilayah DKI Jakarta dan Sekitarnya. Jurnal Sains \& Teknologi Modifikasi Cuaca, 17(1), 21-25. 
Renggono, F. (2002). Analisis Karakteristik Hujan dengan Disdrometer. Jurnal Sains \& Teknologi Modifikasi Cuaca, 3(2), 141-147.

Renggono, F., Hashiguchi, H., Fukao, S., Yamanaka, M.D., Ogino, S.Y., Okamoto, N., Murata, F., Sitorus, B.P., Kudsy, M., Kartasasmita, M., Ibrahim, G. (2001). Precipitating Clouds Observed by 1.3-GHz Boundary Layer Radars in Equatorial
Indonesia. Annales Geophysicae, 19(8), 889-897.

Tikno, S., Yahya, R.B., and Syafira, S.A. (2016). Perbandingan Profil Hujan Vertikal Radar Cuaca dengan Micro Rain Radar Selama Kejadian Hujan Sedang (Studi Kasus : Intensive Observation Period 2016). Jurnal Sains \& Teknologi Modifikasi Cuaca, 17(2), 57-64. 